\title{
When Wall Street manages Main Street: Managerial dilemmas, sustainability, and inequality
}

\author{
Sir John Cass's Foundation Lecture \\ read 2 March 2017 \\ ROSEMARY BATT \\ Cornell University
}

Abstract: Before the Great Recession, financialisation was a 'fringe' concept, but post-recession it moved into the mainstream. In this paper, I begin by reviewing the financial model of the firm, the managerial dilemmas it poses, why it is not sustainable, and why it has led to greater inequality. I then examine alternatives to the financial model - the less visible but important range of experiments in social innovation and institutional renewal that local and regional actors are pursuing to create more inclusive forms of productive enterprise. These experiments provide a testing ground for solutions that may later get to scale. They vary across different contexts, depending on the institutional points of leverage and resources that are available. They include reforms in three domains: labour market institutions, organisational governance, and social finance. The role of academic scholars in this period is to engage with these actors, build an empirical inventory of alternative approaches to productive enterprise, and develop an interdisciplinary analysis of potential models for sustainable and inclusive economies.

Key words: financialisation, private equity, financial model of the firm, firm sustainability, inequality, corporate governance, social innovation, cooperatives, social economy.

Glass House tells the story of the rise and demise of Lancaster, Ohio, a glass manufacturing centre that became the world's largest glass tableware manufacturer over the course of the 20th century. Industrialists built the Hocking Glass Company (later Anchor Hocking) and the surrounding town infrastructure. Their families lived in Lancaster, and their wives created and maintained the educational system and civic culture. Jobs were dangerous and low paying, but stable and backed by union contracts with benefits and pension coverage. In 1982, Anchor Hocking was attacked by 
corporate raider Carl Icahn, but survived. But Lancaster's corporate leaders learned from Icahn's tactics, split the company into two divisions, and sold core Anchor Hocking glass operations to a new owner, Newall Corporation, through a leveraged buyout. Corporate families started leaving town, and civic institutions began to fall apart.

For the next twenty years, Newall sold off assets, extracted union concessions, and used proceeds to buy and sell other companies via leveraged buyouts. In 2004, the company was sold to private equity (PE) firm, Cerberus, in a highly leveraged buyout. Cerberus immediately cut costs, failed to pay for maintenance, cut retiree health care and workers' pensions and benefits, and extracted large rents before bankrupting the company in 2006. It then sold it to another PE firm, Monomoy Capital, which drove it into bankruptcy by 2013. In the meantime, Lancaster had become a central node in the opioid epidemic in eastern rural Ohio - a town festering with unemployment, opiate and heroin addiction, poverty, and illiteracy-with 44 per cent of households led by a single woman in poverty (Alexander 2017).

This is a story about financialisation, not globalisation; and Lancaster is not unique. But in November 2016, Ohio voters assumed the problem was globalisation and voted for Donald Trump - a real-estate tycoon who built his empire on debt and financial engineering.

Before the Great Recession, financialisation was a 'fringe' concept (Froud et al. 2006), but post-recession it moved mainstream. ${ }^{1}$ Many thought a new period of government regulation would emerge, fueled by anger over Corporate Greed - a Polanyian backlash and moment of rebalancing and reigning in financial excess. Instead, the US and Europe experienced regulatory capture by financial institutions, austerity policies throughout Europe, and a rejection of re-regulating capital. Global private equity funds reached a cumulative total of $\$ 4.2$ trillion in 2015 , with fundraising the highest since the bubble years (Bain 2016) — despite the fact that the median fund had not beaten the stock market since 2006 (Appelbaum \& Batt 2018). Similarly, despite underperforming the stock market, hedge funds raised $\$ 71.5$ billion in 2015 , bringing total assets under management to $\$ 3.2$ trillion (Preqin 2016).

In the meantime, less visible are a wide range of experiments in social innovation and institutional renewal that local and regional actors are pursuing to create more

${ }^{1}$ Financialisation refers to two trends. The first is the growing dominance of the financial sector in advanced economies: it represented 10 per cent of corporate profits in 1950 but 30 per cent in 2013 . The second is the growing importance of financial, as opposed to productive activities, in non-financial companies. For example, the ratio of portfolio income (dividends, capital gains, interest payments) to corporate cash flow was less than 10 per cent in the 1960s, 20 per cent in 1980, but 40 per cent in 2000 . Similarly, the ratio of net acquisition of financial assets to tangible assets was 40 per cent or less until 1980, but about 100 per cent by 2000 (Krippner 2011: 36-9). 
inclusive forms of productive enterprise. In this paper, I begin by reviewing the financial model of the firm, the managerial dilemmas it poses, why it is not sustainable, and why it has led to greater inequality. I close by considering the social innovations and emerging institutions that seek to overcome these problems. These experiments provide a testing ground for solutions that may later get to scale. They vary across different contexts, depending on the institutional points of leverage and resources that are available. The role of academic scholars in this period is to engage with these actors, build an empirical inventory of alternative approaches to productive enterprise, and develop an interdisciplinary analysis of potential models for sustainable and inclusive economies.

\section{THE FINANCIAL MODEL OF THE FIRM}

The financial model of the firm differs substantially from the managerial model, which was the dominant corporate form throughout most of the 20th century. Under managerial capitalism, assets are relatively fixed resources used to produce goods and services, while retained earnings replenish those resources and expand the asset base of the firm. Managers with industry expertise have considerable autonomy to invest in operational innovations, and conflicts between management and labour may be offset by managers' need to gain labour cooperation - typically accomplished by sharing with them the gains from productivity growth. The system of managerial capitalism in Anglo and European countries depended on a set of interlocking national institutions, which varied by country, but included securities and banking laws that limited speculative behaviour and provided stable access to capital, and labour laws that allowed workers to negotiate a share in productivity gains (Appelbaum \& Batt 2014, Hall \& Soskice 2000).

The financial model, by contrast, assumes the corporation is a bundle of mobile assets to be bought and sold with the goal of increasing short-term gains and shifting the distribution of retained earnings from investments in the firm and workers to stockholders. Firms increasingly manage for cash rather than profitability. They increase cash returns via a range of financial activities, such as fee-generating activities, the sale of real-estate assets and less profitable businesses, and tax arbitrage. They make greater use of debt for investments - especially favoured when interest rates are low or zero - as debt multiplies returns and the interest on debt is tax deductible. They return the proceeds to stockholders and buy innovation via mergers and acquisitions (M\&As) - which also increases market power-rather than investing in research and development or workforce skills. Because firms extract rents through a range of financial activities, they are less willing to cooperate with labour to generate wealth. 
Leveraged buyout firms (later private equity) developed these innovations in the 1980s - making heavy use of debt to buy out firms and take them private, managing for cash to service the debt, engaging in asset sales and dividend recapitalisations to extract more cash, and exiting companies in a five-year window. Mainstream corporations increasingly mimicked these strategies - as in Lancaster, Ohio. Market deregulation and reregulation helped to create the new institutional foundation for financialisation. Pension reform gave rise to large institutional investors, banking deregulation freed up capital, anti-takeover laws were overturned, union power declined, and enforcement of labour laws was relaxed (Appelbaum \& Batt 2014, Gospel et al. 2014).

As a result, financial activities as a percentage of corporate portfolio income rose from 20 per cent in 1980 to 40 per cent in 2000 (Krippner 2011). The spread of the financial model as a set of assets to be bought and sold is illustrated in the dramatic rise of mergers and acquisitions in the last decade or so. They reached an historic level in the bubble years of 2006-07 before plummeting during the Great Recession. But by 2015, global M\&A activity hit $\$ 4.4$ trillion - surpassing the prior high watermark (Massoudi et al. 2016). Between 2010 and 2015, M\&As grew by 62 per cent in the US (from $\$ 7.9$ billion to $\$ 12.8$ billion) and by 52.7 per cent in Europe (from $\$ 7.3$ billion to $\$ 11.1$ billion) (PitchBook 2016). M\&A activity is driven by strategies to expand market share, reduce costs, and take advantage of excessive cash reserves, which stood at $\$ 1.46$ trillion for the Standard and Poor (S\&P) 500 in 2016. And a 2016 Deloitte survey of 1,000 top corporate managers reported that 75 per cent said they expected deal activity to increase in 2017, 64 per cent expected deals to be larger than before, and 73 per cent planned to shed businesses in 2017 (Deloitte 2016).

\section{Management and organisational strategies}

Three management strategies are central to implementing the financial model of the corporation: executive pay-for-performance, organisational restructuring and outsourcing, and the management of labour as a variable cost.

Most important is the alignment of top management and shareholder interests through executive pay tied to stock options - an innovation that became institutionalised after 1990. By 2015, base salary represented only 11.6 per cent of total CEO pay for the median S\&P 500 company (Tonello and Reda 2015). It represented between 20 and 38 per cent of total pay for top CEOs in all European countries but Italy and the Nordics (Towers Watson 2015). This incentive structure effectively transforms top managers from organisational citizens whose income and reputation depend on building productive enterprises to individual shareholders focused on maximising their

own stock returns before exiting the company (Lazonick 1992). CEOs have incentives to manage for cash to increase dividend payouts and stock buybacks, which raise 
stock prices and CEO pay. These payouts and buybacks have increased markedly in the last two decades. Between 2004 and 2013, for example, these payouts averaged 86 per cent (51 per cent for buybacks and 35 per cent for dividends) of the net income of S\&P 500 corporations, for a combined total of $\$ 5.7$ billion (Lazonick 2014). In another study for the period 2005 to 2015, total payouts for top corporations averaged 109 per cent of the net income of US corporations, 134 per cent of British corporations, and 96 per cent of European corporations (Sakinç 2017). Cumulative research shows that tying executive pay to performance crowds out intrinsic motivation, focuses attention on a specific metric (in this case stock price), and leads to a significantly higher likelihood of earnings manipulation, product safety problems, and shareholder lawsuits (Cable \& Vermeulen 2016).

Second, the focus on short-term cash generation puts pressure on firms to adopt 'lean' organisational structures that reduce headcount. Once firms sell off diversified businesses and develop more focused strategies, they have further incentives to focus on 'core competencies' (what they 'do best'), undertake value chain analysis, and outsource activities that are viewed as 'non-core'. These 'asset light' models of the firm allow companies to lower costs of plant and equipment, labour, and other operational expenses; eliminate legal employment liabilities; and shift risks and uncertainty to contractors and workers in contractor firms. By lowering headcount and reducing the denominator, revenues per employee go up, leading to higher stock market valuations. Notably, while most empirical research has focused on the phenomenon of offshoring and global supply chains (Gereffi \& Koreniewicz 1994, Bair 2009), the use of domestic outsourcing and interfirm networks is widespread in the US and Europe in industries that are relatively untouched by offshoring - including retail, hotels, restaurants, health care, telecommunications, other service industries, and the public sector (Marchington et al. 2005, Darhokoupil 2015, Bernhardt et al. 2016, Doellgast 2016).

A third management strategy turns labour into a variable cost. Recall that a critical breakthrough in labour economics was Gary Becker's book, Human Capital, published in 1964. Becker theorised that labour was more than a variable cost to be minimised, but rather an asset to be invested in - a 'quasi-fixed' factor of production (Oi 1971). That view is consistent with a managerial model of the firm, in which investments in firm-specific training can pay off by creating 'human capital' with unique knowledge and skills - providing a strategic asset for sustainable competitive advantage (Barney 1991). Three decades of empirical research has demonstrated that investments in human capital can pay off - in terms of lower turnover and better operational and financial outcomes (MacDuffie 1995, Appelbaum et al. 2000, Batt 2002, Combs et al. 2006, Jiang et al. 2012). But effective human resource (HR) systems require patient capital and stable employment relations to achieve these results. The financial model, by contrast, adopts the core competency model-segmenting employees into those who 'add value' and those who don't (Lepak \& Snell 1999). A small core is 
retained as a quasi-fixed asset, with the remainder redefined as a variable cost and outsourced. What is core versus non-core, however, is poorly understood (Marchington et al. 2005); and managers often base these decisions on financial pressure to reduce headcount. This approach to segmenting labour misses the essence of any team production view of the firm.

\section{Academic scholars as co-architects}

Academic scholars have been co-architects of the financial model of the firm. The law and economics movement of the 1970s, for example, legitimised the shareholder model of the firm by developing agency theory and arguing that shareholders are the principals and managers the agents, whose interests must be aligned with shareholders (Jenson \& Meckling 1976). It upended longstanding interpretations of US corporate law that viewed the corporation and board of directors as principals, who exist prior to stockholders and who contract with people to provide capital just as they contract with suppliers of other inputs or labour. The law affords stockholders only minimal rights, which include the right to buy and sell stock and to vote (Stout 2012). Agency theory turned this interpretation on its head, arguing that the shareholders are the principals and managers the agents. There is nothing in corporate law that requires firms to maximise shareholder value, but that view became the ideological norm.

Management theorists contributed to the financial model by prescribing core competency theory (Prahalad \& Hamel 1990) — urging companies to focus on their 'core', shed less profitable units, and outsource production-thereby providing quicker returns to investors. Operations and engineering scientists developed systems to codify knowledge, decompose complex systems, and outsource component production around the world. They perfected electronic monitoring systems that allow firms to reduce the indirect costs of supervision and engage in ongoing monitoring, which heightens performance pressures and leads to higher levels of employee burnout (Carayon 1993, Deery et al. 2002, Holman et al. 2002). They developed technologies that shift labour to consumers as 'partial employees' in service production (Lambert 2015).

Economics and HR management scholars contributed by advancing theories of pay for performance for executives (Jensen \& Murphy 1990) and later extending these theories to workers. They prescribed shifting workers' pay from a wage-plus-annualincrease (based on merit or seniority) to a base-plus-variable-pay model in which annual bonuses are contingent on firm performance and are not added to base pay. Workers absorb market risk as their pay rises and falls with firm profitability or the business cycle, over which they have no control. Management scholars also argued 
that firms should shift from full-time employment to flexible staffing models - using part-time and contingent employees to absorb demand shocks - again shifting market risk to workers.

\section{MANAGERIAL DILEMMAS, FIRM SUSTAINABILITY, AND INEQUALITY}

The pressures from this financial model ripple through organisations, creating perverse dilemmas for managers, firms, working people, and affecting the economy more generally. Some are intended, some unintended. Managers' jobs are more difficult, firms lose innovative capacity and sustainability, workers face greater job and income insecurity, and economies face greater problems of inequality (Batt 2018).

\section{Managerial dilemmas}

Managerial dilemmas arise from new and unforeseen agency problems that emerge from tying executive pay to stock options. As CEOs' interests and identities become aligned with those of stockholders, their turnover increases and their commitment to the longterm sustainability of the firm declines. But middle managers are responsible for operational performance and their pay and career mobility are tied closely to operational excellence - quality, customisation, productivity, and time-to-market. These require ongoing investments in process and product innovation that may only pay off long after the then CEO has left. High debt levels and a focus on short-term returns constrain middle managers' ability to make innovative decisions or investments. The high debt levels adopted in the financial model are specifically designed to focus attention on managing cash flow and solving the perceived agency problem that managers' discretion needs to be curtailed and aligned with short-term shareholder interests.

Second and related, while top managers and investors have driven the greater use of mergers and acquisitions, they often fail to fully realise the organisational complications of their decisions. Top corporate managers report that the most important factor for a successful M\&A is the effective integration of organisations (Deloitte 2016), but they often fail to do the necessary 'human capital due diligence' before M\&As occur - leaving managers in organisational disarray to muddle through downsizing and layoff decisions and organisational cultural conflicts (Harding \& Rouse 2007). Meanwhile middle managers are also held accountable for maintaining productivity in the existing organisations, despite heightened job insecurity and overall declines in employee morale. High turnover among middle managers and supervisors often occurs and exacerbates operational disruption and workforce insecurity and morale. 
Third, as supply chains are built out, the performance of the 'core' operations depends heavily on the quality of inputs from suppliers and on the ability of the firm to manage supplier relations. But procurement departments, not middle managers, typically control the supply chain. A salient example is the Boeing 787 Dreamliner project. After the MacDonald Douglas-Boeing merger, the leadership increased its focus on short-term returns and decided to outsource over 60 per cent of component production for the new plane-based on consultant estimates that this would save $\$ 4$ billion and reduce development time by two years. It contracted with 50 tier-one suppliers, who would oversee two tiers of additional suppliers. But Boeing's top managers grossly miscalculated costs and underestimated supply chain complexity and the critical link between engineering and manufacturing. Boeing engineers, managers, and workers were inundated with poor-quality parts that had to be reworked; faced serious safety problems, for example, with lithium batteries; and confronted massive coordination problems - leading to a 3.5-year delay in production and $\$ 10$ billion in cost overruns (Tang \& Zimmerman 2009, Denning 2013, Tang et al. 2013).

\section{Firm sustainability}

There are several reasons why the financial model ultimately may not provide sustainable competitive advantage relative to other emerging organisational models, such as Asian business conglomerates or state capitalist enterprises. As the holding period for stockholders has continued to fall (to a median of about 10 months in 2014 (Mayer 2015)), executives feel even greater pressure to produce short-term returns. Their corporate performance is measured according to how efficiently capital is used, or profit per dollar of capital. This creates incentives to invest in efficiency-enhancing innovations that substitute technology for labour and pay off in the short-runhelping companies produce and market mature products at lower prices. By contrast, market-creating innovations that build longer term sustainability and create more jobs require substantial amounts of patient capital (Christensen \& Clark 2014). Investor pressure to shift the distribution of retained earnings to shareholder dividends and stock buybacks and reduce investment in $\mathrm{R} \& \mathrm{D}$ and innovation also undermines long-term capacity-building and competitiveness (Lazonick 2009).

In addition, the heightened M\&A activity - coupled with large accumulated cash reserves in top corporations - had driven up the cost of strategic acquisitions to almost $10 \times$ EBITDA by 2016 (earnings before interest, taxes, depreciation, and amortisation) - a very high cost that intensifies pressure on firms to manage for costs to recoup the investment (PitchBook 2016). The high cost of acquisitions has driven down the returns on investment. To take one example, econometric studies of the 
returns to private equity leveraged buyouts show that the median PE fund has not beaten the stock market since 2006 (Appelbaum \& Batt 2018).

High M\&A activity also causes ongoing operational disruption and lower quality and productivity. The jobs of CEOs are also more difficult, and CEO turnover has increased - contributing to operational disruption. CEO turnover averaged 8-9 per cent in the mid-1990s (Lucier et al. 2004), but 15 per cent in the late 2000s-reaching 16.7 per cent annually in 2015 (PWC 2015) - according to research based on the top 2,500 largest global corporations. This churn particularly undermines financial performance for firms that increasingly rely on quality, value-added customisation, and stable client relationships as the source of competitive strength. An estimated 70-90 per cent of M\&As fail, according to accumulated empirical research on the topic (Christensen et al. 2011, Martin 2016).

Another indicator of the lack of competitiveness of the financial model is the relative success of other models of doing business around the world. Asian business groups, Chinese enterprises, and other emerging market multinational corporations (MNCs), which rely on very different business models or state subsidies, are fierce global competitors (Khanna \& Palepu 2006, Guillén \& Garcia-Kanal 2009). By 2008, the US accounted for roughly 20 per cent of world gross domestic product, down from 27 per cent in 1990. Only four of the ten largest corporations were based in the US, down from eight in 1980 (Forbes 2009).

\section{Worker insecurity and growing inequality}

A growing body of evidence also shows that the financial model has contributed to lower wages and greater income inequality within advanced economies. A number of financial and organisational strategies allow firms to extract more rents than in the past, regardless of whether they contribute to value creation. ${ }^{2}$ Financial intermediaries, such as private equity and hedge funds, have substantially increased their assets under management and their power to extract rents by intervening in the financial strategies of non-financial firms (Appelbaum \& Batt 2014). They extract rents through speculative activities as well as fees that they charge investors and portfolio companies, which also appeared to have grown in recent years, although accurate data is not available (Appelbaum \& Batt 2016). One estimate by Warren Buffett, chairman of Berkshire Hathaway, is that shareholders - especially pension funds-have lost $\$ 100$ billion in fees to hedge funds, private equity, and money managers in the last decade as their fees have grown substantially. He has routinely counselled them to put their money in a low-cost S\&P 500 index fund (Sorkin 2017).

${ }^{2}$ See Appelbaum (2017) for a full elaboration of these arguments. 
Shareholders have extracted greater rents through higher dividends and high share prices associated with stock buybacks - shifting upward the distribution of earnings at the expense of other stakeholders. Mergers and acquisitions also create firms with greater market power and ability to charge monopoly rents. Ownership concentration has increased considerably since 2000 - in 90 per cent of US industries according to one study (Grullon et al. 2015). And a recent study of M\&A transactions in US manufacturing demonstrates these effects: It found no positive effect of M\&As on productivity or efficiency from 1997 to 2007, but instead found price mark-ups ranging from 15 to 50 per cent, depending on model specification (Blonigen \& Pierce 2015).

The vertical disintegration of the firm into supplier networks also contributes to greater income inequality. This may occur through changes in labour market rules or changes in inter-firm power relations. Labour market rules in large and small firms differ. Large primary firms are more likely to be unionised, and even large non-union firms typically set wages by administrative rules in which internal equity norms or efficiency wage considerations lead to compressed wage structures-raising the bottom. When low-skilled jobs are outsourced, workers' pay is delinked from that of higher skilled workers and becomes more market based.

Even higher skilled workers, however, may suffer when their jobs are outsourced. When lead firms shift production to networks of suppliers, each node in the network becomes a profit centre and a potential point of rent extraction. Lead firms typically have the power to set the terms, conditions, and pricing for tier-one suppliers and to create a competitive bidding process among them that puts downward pressure on profit margins. They shift market risks and legal liabilities to suppliers and often require them to absorb inventory and other costs. These organisational strategies allow the more powerful firm to extract greater rents. This process may occur at successive nodes in the network - squeezing profit margins at each link and putting downward pressure on wages and benefits for workers. Thus, inequality grows via increased rent extraction at the top and depressed wages at the bottom (Appelbaum 2017).

A growing body of empirical evidence supports these arguments. Research on low-skilled workers has found substantial pay and benefit penalties for call centre workers in outsourced operations (Batt \& Nohara 2009, Doellgast et al. 2016) and janitors and guards, compared to those in in-house operations (Dube \& Kaplan 2010, Goldschmidt \& Schmieder 2015). More generally, national studies show that increased inequality is due to increased earnings dispersion across establishments and firms (Barth et al. 2014) as well as the occupational concentration of workers across establishments (Handwerker 2015, Handwerker \& Spletzer 2015). Contracting out also is associated with a higher incidence of workplace injuries (Rebitzer 1995, Morris 1999, Muzaffar et al. 2013, Foley et al. 2014). 
The franchising system is another form of outsourcing in which franchisors in recent decades have developed strategies to extract higher rents. It has expanded substantially across industries and around the globe. In the US, 10 per cent of US businesses are franchisees (US Census Bureau 2010), and they employ 6 per cent of the US workforce (IFA 2013). In this model, the franchisor receives an initial fee for use of the brand and monthly royalties (rent) based on gross sales in the range of 6-10 per cent. Franchisees absorb all the risks and legal liabilities and retain the profits. Early franchise agreements created a bright line between the franchisor and franchisee, granting the latter considerable autonomy. But that bright line has blurred, with franchisors now exerting much greater control through detailed operating manuals, 'remote management' via payroll and software systems that monitor staffing levels, and required use of preferred suppliers in which the franchisor often has a financial interest. The franchisor also requires the franchisee to cover the costs of operational improvements that enhance gross sales, to the benefit of the franchisor, but may squeeze franchisee profit margins. Franchisees often go into debt to set up a franchise, and their cost of capital is typically higher than that of franchisors. This incentive system pushes franchisees to manage for cash and focus on operating costs, the majority of which are labour costs. In addition, franchisors are increasingly adopting 'asset light' models by turning most or all of their operations into franchises.

Empirical studies show that the logic of the franchise systems translates into lower wages and working conditions in franchisee operations compared to those in franchisorowned establishments (Lakhani 2016); and wage and hour violations are also significantly higher in franchisee workplaces (Weil 2014, Ji \& Weil 2015).

\section{RE-EMBEDDING ENTERPRISE: SOCIAL INNOVATION AND INSTITUTIONAL CHANGE}

Scholars have a responsibility to help solve the problems of unsustainability and inequality associated with the financial model of the firm. And many are doing so. A slew of new books tackle these issues: How Will Capitalism End? (Streeck 2016), Rethinking Capitalism (Jacobs \& Mazzucato 2016), Firm Commitment (Mayer 2013, 2015), The Vanishing American Corporation (Davis 2016), Cooperatives Confront Capitalism (Ranis 2011), The Social Economy (Amin 2009), Manifesto for the Foundational Economy (Bentham et al. 2012), Social Finance (Nicholls et al. 2015), and many more. This is an important time of intellectual discovery and debate.

No one new dominant model of productive enterprise is likely to emerge in the near future, but alternative models that are less competitive now—or new models that 
emerge - may hold potential. An historical analogy is the dominance of the US mass production model of manufacturing in the 20th century. New technologies emerged in the 1980s that facilitated batch production of high-quality diversified products; and regions that had sustained manufacturing based on clusters of small interdependent firms were able to take advantage of these new conditions and compete effectively. Mass production manufacturing suffered and had to reinvent itself by incorporating new forms of networked production (Piore \& Sabel 1984).

Economic or management theory alone cannot provide a guide to new solutions. Enlightened corporate behaviour is important, but limited by voluntarism. For example, while European MNCs are more advanced in their commitment to corporate social responsibility compared to others, a recent global survey found that only 4 per cent of 3,000 MNCs made a clear commitment for all human rights areas for which they are responsible (Virgeo Eiris 2017). National legal and regulatory solutions are theoretically plausible, but politically improbable in the current period of polarised civil societies.

Rather, a range of new approaches are emerging based on variation in the institutional points of leverage available in different local and regional contexts. Practitioners, small businesses and associations, union and community members, and policy makers are deeply engaged in social innovation: labour movement activities, alternative models of organisational governance, and local experiments in social finance to re-embed productive enterprises in the 'social economy'. Social and institutional innovations at the local level provide a testing ground for experiments that may later get to scale.

For these solutions to take root, it is important to look beyond the firm or the networked firm as the unit of analysis and to examine institutional networks of political and economic actors and the points of leverage available for social innovation in different contexts. Because existing theoretical models are insufficient, it is important for social scientists to return to the field to observe and monitor the viability of a wide range of current social experiments. And because our research question is problem-centric and multi-dimensional, the answer needs to draw on a range of disciplines that offer distinct angles on the problem. While academic disciplines are still siloed, scholars may collaborate across boundaries to develop new interdisciplinary insights. Three points of departure are noteworthy: Research on labour institutions and social movements, on alternative models of management and corporate governance, and on new forms of social finance. Each has strengths and weaknesses, but may be viewed as providing the building blocks for new models of 'social economy.' 


\section{Labour institutions and social movements}

Innovations in labour and social movement organising provide one point of leverage for re-embedding the corporation. They do not challenge the financial model of the firm, but rather create better lives for working people in the immediate period, engage a new generation of leaders, and build innovative tactics and institutional capacity. During the past few decades, most industrial relations research has focused on the decline in union density and bargaining power and the fraying of industrial relations systems, but more recently researchers have begun to document alternative approaches to labour revitalisation. These grow out of existing systems across different nations.

In Europe, for example, as national industrial relations systems have frayed in the face of globalisation, scholars have tracked union innovations that respond to European integration and develop new forms of multi-level bargaining that go beyond existing national industry frameworks and create interlocking governance structures at the national, regional, and international levels (Marginson 2016). Another set of researchers are examining new models of collective action and representation that respond to the rise of domestic outsourcing and inter-firm production networks (Doellgast et al. 2017).

In the US and Canada, by contrast, industrial relations systems are much more fragmented and firm-centric, presenting labour advocates with a different set of problems and points of leverage. Firm-based union elections and bargaining, as required by New Deal labour laws, undermine labour power and delay union representation elections. As US corporations more aggressively fought unions from the 1970s on and union density declined, unions began to mobilise workers across firms; and non-union organisations - referred to as 'workers' centres' - began to directly confront non-union employers and demand workers' rights (Fine 2005).

A noteworthy example is the 'Fight for Fifteen' to achieve a $\$ 15$ minimum wage. It began in November 2012, when 200 fast-food workers went on a one-day coordinated strike against seven major chains at in New York City. From there, organisers built capacity to conduct coordinated one-day strikes across US cities. The coordinated strike went international in 2014 -with 230 cities participating in 2015, including 80 in 33 countries on six continents (Fight for Fifteen 2015, Greenhouse 2016, Zahn 2016). By November 2016, some 600 cities participated internationally-the twelfth and largest one-day strike. And in 2016, the Democratic Party adopted the $\$ 15$ minimum wage as part of its convention platform.

In four years, by the end of 2016, 54 states and cities had raised their minimum wage, affecting an estimated 20-22 million workers. Of those, 60 per cent are on a path to $\$ 15$ per hour - due to city-wide ordinances in major cities (Seattle, San Francisco, Los Angeles, and Washington, DC) and state-wide laws in California and New York. 
Over 7 million will receive wage increases below that level. The campaign also led scores of private sector employers-including The Gap, Starbucks, WalMart, J.P. Morgan, and several universities - to 'voluntarily' raise their minimum pay to $\$ 15$ or more (Chandler 2016, NELP 2016). Notably, striking workers have not lost their jobs because of innovative 'walk back' strategies in which workers return to work accompanied by a large group of community leaders from churches, city councils, unions, and other civic organisations.

To put this movement into perspective, in 2016 US unions represented only 7.4 million workers private sector worker-or 6.7 per cent of the US workforce. By contrast, in just four years, the 'Fight for Fifteen' has affected an estimated 12.5-14.5 per cent of the US workforce. For a majority of those workers, the $\$ 15$ per hour wage will mean a 50 per cent wage increase or more - with annual wages for full-time workers going from $\$ 18,000-\$ 20,000$ per year to $\$ 30,000$ - a monumental change in living standards.

The central question is whether the movement can become institutionalised. The skeptical view is that the movement has been funded almost entirely through the Service Employees International Union (SEIU), at an estimated cost of $\$ 70$ million in four years (Zahn 2016). The optimistic view is that it has produced an ideological shift that is unlikely to unravel and has built a new generation of leaders using innovative tactics that move beyond firm-level collective bargaining to gain mass public support. In 2012, the idea of a $\$ 15$ an hour minimum was viewed as absurd; soon it became mainstream thinking. Some businesses now support the minimum wage due to its positive impact on revenues, as higher paid low-wage workers spend more on basic living expenses in local communities. In November 2016, the 'Fight for Fifteen' held its first national convention to launch a plan for a sustainable organisation-with several thousand workers attending. And the national approval rating for US unions increased from 52 per cent prior to 2012 to 58 per cent in 2016 (Hartung 2016, Zahn 2016).

In addition, the Fight for Fifteen did not emerge 'de novo', but rests on over two decades of experimentation by seasoned leaders and young activists in four interlocking movements: unions, non-union workers centres, immigrants' rights groups, and civil rights organisations. In the 1990s, community groups and unions organised 'living wage campaigns' to get city councils to pass higher minimum wages for workers at firms with city contracts, with 140 ordinances passed as of 2013. Unions like the SEIU developed new organising strategies working with community and religious organisations and moved to city-wide campaigns to organise workers across tiers of contractors, as in the 'Justice for Janitors' campaigns (Erickson et al. 2002). In parallel, city-based workers' centres began representing non-union workers and negotiating directly with employers to improve employment, wages, and working conditions. 
An estimated 250 centres existed in 2015-coordinating strategies through sectoral networks of centres across the US (Cordero-Guzmán 2015). Similarly, immigrant workers' rights organisations and 'Black Lives Matter' have built networks of civic organisations (Gleeson 2012). The thirty-year history of building interlocking networks of labour and community organisations suggests that, while still fragile, they have become a new institutional point of leverage for labour in the United States.

Critics worry that the rise in the minimum wage will lead to higher unemployment, but the overwhelming bulk of econometric evidence does not support this view (Allegretto et al. 2017). Rather, recent research shows that the higher wage is almost entirely absorbed through modest increases in consumer prices, in the range of 5-7 per cent (Allegretto \& Reich 2018). These modest increases are more than offset by the increase in disposable income among low-wage workers, which is ploughed back into the local economy. In sum, local businesses may benefit as well.

\section{Management and corporate governance}

A second body of research has explored a range of alternative forms of corporate governance as a solution to sustainable enterprises. Two models have received noticeable attention: the conglomerate model, as developed by Asian business groups such as the Tata group, and the cooperative model, as developed in the classic case of Mondragon. Surprisingly, they have important features in common.

In contrast to discredited Western conglomerates, the Tata model consists of a privately held holding company that has controlling shares in a set of publicly listed independent subsidiaries with autonomous CEOs and boards of directors. The parent company finances initial investments and establishes strong norms, but does not interfere with business operations. The brand adds value to the business groups; and the parent facilitates cost-effective inputs via economies of scale, quality management standards and common procurement systems, and centralised ancillary servicessuch as legal, finance, accounting, and HR services. Group members pay a percentage of profits for these services, with new groups or those that do not make a profit essentially subsidised by gaining free access to these services. The parent firm minimises hyper-competition by limiting the growth of its subsidiaries in overlapping markets and by financing and promoting spin-offs into diversified products and markets. These independent companies create their own demand through supplier networks. The lack of competition among business groups facilitates a process of knowledge sharing and synergies at the operating level. The legally independent structure also means that there is no ripple effect across the Tata footprint if some businesses fail. Substantial investment in human capital and a stable internal labour market provide long-term employment and income security (Chittoor et al. 2013, Ramachandran 2013). 
The paternalistic culture is built on shared values undergirded by the Parsi religion. In 2016, Tata had $\$ 120$ billion in assets under management and about 660,000 employees.

The classic Mondragon model has similar financial and organisational features, but with a democratic governance structure. The financial backbone is a cooperative savings bank in which all members and cooperatives are required to deposit their savings. This provides low-cost loans to members and finances new cooperatives. Co-ops are limited in size to 500 in order for members to meaningfully participate in governance via a one-member, one-vote rule. Each co-op has a governing council (board of directors) elected by members; a top management council, which consults with an employee-based 'social council;' and a financial audit committee. A noncompete clause exists to discourage co-ops from cannibalising themselves and to encourage the build out of cooperative enterprises across sectors - manufacturing, agriculture, retail, services, marketing, consumption, education, and an unemployment and social security system. Over time, the federation became a network of suppliers and buyers, creating its own demand - a vertically integrated system from raw materials to sales. The educational cooperative provides a steady supply of technically skilled workers and, as it is integrated into networks of enterprises, adjusts its training as the demand for skills in the region changes. Workers can move across employers for jobs; employment stability is favoured over wage gains; and wage differentials are kept to a minimum. Mondragon had some $\$ 30$ million in assets and 80,000 employees in 2013 (Tremlett 2013, Latinne 2014, Szekely \& Dossa 2014).

Both of these models, however, grew out of specific institutional conditions that are difficult to replicate elsewhere. Both faced an institutional void in capital markets. Both are built on relations of trust and shared values among family and community members that undergird participation, shared risk-taking, and willingness to crosssubsidise the growth of additional enterprise units. Notably, Mondragon has largely failed in its efforts to export the cooperative model to its international operations.

Parallels to the Tata model are found in Europe where some corporations still rely on the use of family trusts or industrial foundations that create the basis for committed capital. This may be a source for the further development of this model in Europe (Mayer 2013, 2016). In the US, one effort to create an alternative to the shareholder model is the 'Benefit Corporation' - which in contrast to traditional corporations, is a legally incorporated for-profit enterprise with explicit social as well as profitability goals. Benefit Corporations are legally authorised in 30 US states and are required to maintain higher standards of accountability and transparency than traditional corporations. 'B Lab' - a non-profit agency that originated the concept and certifies companies based on their conformance with social, environmental, accounting, and transparency standards - has certified some 2,000 Benefit Corporations in 50 countries 
and 130 industries. ${ }^{3}$ This is part of a larger interest in the area of social entrepreneurship or social enterprise, which has gained traction in leading business schools as many MBA students seek ways of 'doing well by doing good' or mitigating the negative social and environmental impacts of multinational corporate expansion across the globe (Smith et al. 2013). Business schools, then, may provide an institutional base for building out these types of new models.

The cooperative movement has gone through waves of enthusiasm and experienced a new wave with the spread of anti-corporate ideology following the Great Recession (Ranis 2016). The United Nations declared 2012 'the International Year of Cooperatives'. Some forms of the co-op model have been institutionalised. The most successful and widespread are those designed for group purchasing to reduce input costs, consumer cooperatives to reduce the price of food and basic necessities, and mutual associations or credit unions. The scale and scope of the cooperative sector worldwide are difficult to estimate given data limitations. But cooperatives play an important role in many economies - most heavily concentrated in insurance, agriculture and food, wholesale and retail, and banking. They have become institutionalised through a series of national and international confederations, the most important of which is the International Co-operative Alliance (ICA). It reports a membership of 700 million individuals worldwide. Recent research has documented an estimated 1,465 very large and successful cooperatives (with annual revenues of $\$ 100$ million or more) worldwide - with the largest numbers found in the US, followed by France, Japan, Germany, The Netherlands, Italy, and Spain (Birchall 2013).

Scholars and policy makers in the US point to the deep legacy of 'mixed' or alternative organisational forms of enterprise as a potential source of renewed economic development in the post-Recession period. Co-op, mutual, local, and state-owned enterprises emerged in the 20th century at the same time that large for-profit corporations were becoming dominant. They provided the economic backbone for rural communities and small towns - with agricultural producer co-ops forming a core that led to the expansion into other types of co-ops or mutual enterprises - including buyer and consumer co-ops, insurance mutual, municipal utilities, electrical cooperatives, and credit unions. These mixed organisational forms tended to cluster in communities that were stable and homogenous, in those with large Scandinavian or German immigrant populations, and agricultural communities waging anti-corporate or reform campaigns against financial elites. These regions developed dense networks of organisations that supported ongoing economic development (Schneiberg 2011). In the current period, an estimated 30,000 cooperatives exist in the US with over $\$ 3$ trillion in assets, $\$ 650$ billion in revenues, and 2 million jobs (University of Wisconsin 2010).

\footnotetext{
${ }^{3}$ https://www.bcorporation.net/what-are-b-corps/about-b-lab
} 
Some 12,000 employee-owned companies in the US (via Employee Stock Ownership Plans) also serve as an alternative to the shareholder model (Abell 2014).

But worker-owned productive cooperatives, similar to Mondragon, are rare. They often emerge in response to economic crisis - as in Argentina after the 2001-2 crisis, when workers took over factories and converted them to co-ops (Ruggeri \& Vieta 2015, Azzellini 2017). They face barriers to entry-high risks for workers, lack of access to capital, lack of business expertise, and ideological opposition. The democratic governance model is more difficult to achieve and maintain over time compared to more hierarchical models. The model also sets limits to growth as members cannot sell shares to finance new ventures, they rely on loan finance, and they lack access to external finance (Olsen 2013, Diamantopoulos \& Bourgeois 2014).

Nonetheless, once established, some evidence shows that cooperative businesses and banks have higher survival rates than their conventional counterparts. In Europe, they outperformed their counterparts during and after the financial crisis (Birchall \& Ketilson 2009). Similarly, recent studies find that US and Canadian cooperatives have longer survival rates and are more resilient than comparable small for-profit businesses (Olsen 2013, Abell 2014). Thus, cooperative growth appears to depend less on survival rates and more on barriers to entry - that is, whether the institutional conditions exist to support their adoption - particularly financing in the early years.

To this end, the International Cooperative Alliance launched a 'Blueprint for the Co-operative Decade', with the goal of expanding adoption and developing modern financial instruments and accounting standards to support the business model (ICA 2014). In the US, several US cities have developed programmes to support cooperative development. In 2016, the mayor of New York allocated $\$ 1.2$ billion to support local worker cooperatives in the city. Cleveland, Cincinnati, and other deindustrialised heartland cities are promoting cooperatives to serve as local suppliers to 'anchor institutions'-hospitals, universities, and government entities that are immobile. These institutions have a self-interest in reducing poverty and unemployment in their localities. Hospitals, for example, which serve the communities in which they are embedded, can cut health care costs and utilisation rates by reducing poverty and creating more stable communities (Howard \& Norris 2015).

In sum, both the business group-industrial foundation model and the cooperative model, in all of its various forms, provide alternative approaches to organisational governance that are worth paying attention to.

\section{Social finance and the social economy}

New forms of management and organisational governance require new forms of finance. A starting point is to challenge the idea that the 'shareholder class' is homogenous, but 
rather has diverse preferences. While activist investors are known to demand quick returns, they constitute a minority of investors; others are risk averse or prefer more stable, long time horizons and are willing to accept lower returns. Several mechanisms exist for shifting shareholder preferences to longer term commitment: for example, by awarding enhanced voting power or extra dividends (L-shares) to longer term shareholders or providing bonuses to facilitate investment in long-term innovation and development (Christensen \& Clark 2014).

Other investors may be more interested in social or environmental goals rather than financial ones. The emerging field of social impact investment has identified a range of mechanisms for investing in enterprises that have explicit social and environmental goals in addition to in financial ones (Nicholls et al. 2015). The broad field of social finance includes a wide array of concepts and forms: impact investing (for a specific social or environmental purpose), social investment (repayable capital for social sector organisations), community finance, crowdfunding, mutual finance, green investment, ethical banking, private-public partnerships, and the like. Notably, interest in this area has taken off in business schools, which now typically offer courses in social entrepreneurship, social impact investing, or the social impact of the corporation. Leading business schools in the UK, US, Europe, Canada, and Australia have established research institutes in this area as well (Daggers \& Nicholls 2016).

One type of social finance that is beginning to get to scale in the US is the Community Development Financial Institution (CDFI). The idea originated with the formation of the National Association of Community Development Loan Funds in 1985. The goal was to create equitable access to capital for low-income communities. CDFIs are private financial institutions that finance small businesses, microenterprises, nonprofit organisations, commercial real estate, and affordable housing. CDFIs were initially funded primarily by individuals, religious organisations, and the National Cooperative Bank. Now they include banks and bank holding companies, credit unions, loan funds, and venture capital funds - each with a different legal structure and distinct mix of financial products and services to meet specific needs. While initially focused on affordable housing, CDFIs now fund a wide range of enterprises that serve community economic development. In 2016, the industry was comprised of almost 1,000 organisations managing \$108 billion in assets (CDFI Fund 2016, FDIC 2016)

In the 1990s, the Clinton administration began to fund CDFIs through government funds and tax breaks to private sector investors with the goal of creating dedicated streams of finance for community economic development. Since then, about $\$ 35$ billion in funds have been invested in new business and small enterprise development in communities across the US. In 2009, Goldman Sachs launched a \$300 million initiative to fund CDFIs over several years to support small enterprise development (OFN 2010). 
Assessing the impact of these experiments is difficult given their recent development and the lack of adequate data. But they are important in their explicit rejection of the financial model of the firm. Research in this area is important for constructing specific finance and accounting mechanisms and techniques that are viable. The approach is limited in that it does not address how social enterprises treat labour within their own organisations. And their broader impact depends importantly on whether they are small islands of excellence in the larger economy - based on individual entrepreneurship - or whether they are embedded in local and regional institutions and part of an integrated approach to economic renewal. Here, experiments that bring together labour, alternative forms of governance, and alternative forms of social finances appear to be the most promising in creating inclusive or 'social' economies. The province of Quebec, Canada represents the most advanced example of an integrated and systemic approach.

The Quebec model emerged out of economic necessity in the 1980s and 1990s. It builds on local institutional strengths - a large unionised workforce (still at 40 per cent) and a history of concertation between business, government, and labour. A key development was the creation of voluntary pension funds by two of Quebec's largest union federations - allowing the labour movement to invest directly in economic development and job creation. At the same time, a growing set of community groups and social activists pressured government to respond to problems of poverty and unemployment-leading the provincial government to incorporate these groups as a 'fourth partner' in the concertation process. Then Premier Lucien Bouchard held a socio-economic summit of the four sectors and developed a programmatic approach (Le chantier de l'economie social) or the route to the social economy-defined to include 'collective entrepreneurship, cooperatives, and mutual associations'. Public funds supported social enterprises for basic services-homecare, daycare, environmental services - as well as training and business development; and a public-private investment fund provide loan capital for social enterprises of all types (Mendell 2009).

The Chantier became a non-profit organisation with representatives from the labour movement, community groups, and cooperatives in 20 sectors of the economy. It represents this network of networks in ongoing dialogue with local, regional, and provincial governments to advance supportive policies - in what they term the 'coconstruction of public policy'. While Quebec has a strong private sector economy, the 'social economy' grew alongside it. By 2002, the social economy included 7,800 cooperatives, $\$ 102$ billion in business activity, and 160,000 workers. Through the 2000s, the Chantier built an integrated institutional architecture that includes a network of organisations providing finance, research, training, and business services-an integrated system of social innovation. Investment in the social economy between 1996 
and 2006 totaled $\$ 755$ million (Mendell 2009). By 2006, 7,000 people were employed by the province's 184 worker cooperatives and another 14,000 in worker shareholder or 'multi-stakeholder' cooperatives. Combined, these worker-inclusive cooperatives accounted for a third of all jobs in Québec's non-financial cooperative sector in 2008 (Clement 2009).

Social finance is a critical part of this story. Collectively owned enterprises cannot issue shares, and the majority of financial products available to them are short- or medium-term loans which provide limited support for expansion. Quebec's solution was a series of innovations in 'solidarity finance,' including a union-based credit union for cooperatives, a social investment fund (Fiducie), backed by government and union pension funds, offering long-term loans to capitalise social economy initiatives; a regional development fund backed by tax credits; a Co-operative Investment Plan (CIP) tax credit to shelter workers from the double risk of losing their investments and their jobs; and other specialised instruments to meet a full range of capital needs. The Chantier's Fiducie conducts ongoing economic research in collaboration with universities, works with local community development agencies to identify opportunities for growth in different sectors, and in recent years has particularly focused on building investment funds to support social enterprises in Montreal's vibrant arts and culture sector - a major source of tourist revenues (Mendell 2009, Diamantopoulos \& Bourgeois 2014).

Estimates of the cumulative economic effect of the Quebec social finance innovations are not available, but a recent study does report on the union Solidarity Fund alone. In 2016, it had a total of 12 billion in assets, 40 per cent of which was invested in equity and 60 per cent in venture capital. Its returns for the five-year period ending in 2016 were 6.8 per cent, when North American hedge funds averaged 5.9 per cent. The authors report that the fund has been successful as a source of patient capital for small and medium-sized enterprises and that it has contributed to job creation in the province of Quebec - its initial mission. The fund encourages its 'partner firms' to rely on local suppliers and skilled labour. It invests in projects that offer a lower profit rate if there is an important social rationale for doing so. It does not exit companies due to poor short-term performance. When a firm is in financial difficulty, the fund typically retains its investment and seeks to help with restructuring to maintain employment security to the extent possible. Before selling its stake in a company, it undertakes an 'exit social audit' to make sure that the disinvestment does not lead to job loss. At the same time, the authors also caution that the fund is in competition with other funds on the Quebec capital market, which sometimes pushes the Solidarity Fund to make investments that some unions oppose because the investments do not meet the necessary 'social criteria' (MacDonald \& Dupuis 2017). 


\section{CONCLUSION}

Returning to the Glass House, I want to bring together the threads of my paper. Financialisation emerged as an economic, political, and ideological force from the 1980s on, in which powerful financial and corporate actors captured regulatory institutions and deregulated and re-regulated them in ways that favoured their interests. While there is nothing in corporate law that requires firms to maximise shareholder value, that ideology became the norm. The financial model of the firm has contributed to job instability and income inequality via interrelated innovations in finance, business strategy, operations, HR management, and relations policies. Financial policies made greater use of debt financing and shifted retained earnings from reinvestment in R\&D to dividend payouts. Business strategies shifted from organic growth via investments in innovation to the buying and selling of assets via M\&A activity-leading to ongoing operational disruption and confusion in existing business units. Management theory privileged the core competency model and legitimised the sell-off of otherwise productive units and the outsourcing of work to multiple tiers or complex networks of suppliers. Operations management perfected the modularisation of production. HR management policies linked executive pay to stock options, providing incentives for heightened use of stock buybacks to artificially raise share price; while shifting risks to workers through greater use of variable pay. And employment policies often re-conceptualised human capital as a variable cost to be minimised, rather than a quasi-fixed asset of production.

These policies have allowed financial and corporate leaders to extract higher rents from productive organisations, have undermined the capacity of managers to build innovative capacity, and have also contributed to increased inequality within countries. In this process, globalisation has served as a tool for financial actors to move capital around the globe. They have used new digital technologies as tools for organisational change - to outsource work, avoid employment liabilities, and substitute technology for labour.

The modern corporation has evolved from a managerial model based on operational innovation to one based on marketing innovation to an emergent model based on financial innovation and control. We are now in a period of social innovation. Scholars from a wide swathe of disciplines have recognised the unsustainability of the financial model of the firm and for the economy more generally, and are engaged in a critical debate regarding more viable models of social economic growth and development. Practitioners and policy makers are engaged in what is likely to be a sustained period of organisational and institutional experimentation.

Proposals for national or international regulatory reform are theoretically plausible, but most lack the institutional and political capacity to be implemented in 
the near future. However, local experiments and the research documenting their challenges and successes provide the basis for incremental change and policy and regulatory reforms at the local, state, and provincial levels. As I have argued in this paper, to reduce the power of financialisation and shift to environmentally and socially sustainable business practices requires action across a wide set of actors with different approaches and points of leverage. Here I highlight a few salient examples.

First, some initiatives do not require legal or regulatory reform. For example, research in corporate governance has identified a set of alternative models to the corporation that rest on social mechanisms for raising capital, investing in productive enterprises, and cross-subsidising the growth of innovative enterprises. Social entrepreneurs and creative investors are using a wide range of strategies for raising funds for enterprises that do not privilege shareholder maximisation-including impact investing, social investment, community finance, crowdfunding, mutual finance, green investment, ethical banking, and the like. These types of initiatives have grown rapidly in recent years, and business school students appear eager to learn about them and apply them.

In addition, corporations already have the power to create incentives for longer term shareholding and patient capital to reduce short-termism (Christensen \& Clark 2014); and there is increasing demand by socially conscious investors to hold corporations accountable for meeting environmental, social, and governance (ESG) standards. Nobel Prize-winning economist, Oliver Hart, provides a model of the corporation that is consistent with current corporate law, based on maximising shareholder welfare, not profit. He argues persuasively that boards of directors have discretion to define their fiduciary responsibility more broadly than profit maximisation based on the assumption that shareholder preferences are heterogeneous and socially conscious (Hart \& Zingales 2017).

Legislative or regulatory reforms - often stymied by national-level political conflict - have been more successful at lower levels of government. One example, noted above, is the passage of state-level legislation explicitly sanctioning the incorporation of forprofit enterprises with explicit social goals (Benefit Corporations) - a reform that has expanded rapidly around the world. Similarly, in the US, where the federal government has failed to pass reforms to employment laws, including minimum wage laws, local and state-level actors have rebuilt power by mobilising activists across race, gender, and class divides - leading to the passage of minimum wage and living wage laws in over fifty jurisdictions. Local and state activists have also expanded the range of substantive areas subject to regulation-for example, in such areas as paid sick leave, paid family leave, domestic workers rights, and employer scheduling practicesareas in which the federal government has failed to act. In other words, they have succeeded in passing regulations that go beyond the traditional areas regulated by the 
federal government. Five states, twenty-three cities, and one county have enacted paid sick leave laws. Six states have passed domestic workers bills of rights, and a hundred cities and counties have 'banned the box'-removing conviction history questions on job applications. Efforts are also underway to create local policies to tackle unfair scheduling practices and expand paid family leave.

A particularly important area for legal reform is in the area of banking and finance for alternative ownership models. I note examples of the creative use of government funds or tax breaks to create financial tools for local economic development, but these are at very early stages of development. The Quebec story provides a powerful model of how public funds can harness private funding when coupled with creative thinking about how to develop a range of different types of financial products for collectively owned enterprises. Cooperatives continue to face legal obstacles that must be overcome if they are to be successful and get to scale.

Each approach has vulnerabilities in building capacity, getting to scale, and becoming institutionalised. In the current period, the most promising solutions appear to rely on existing institutional resources as points of leverage. They are geographically embedded and start at the local level where shared interests and trust provide the basis for negotiating solutions that may be mutually beneficial. This suggests that in the intermediate term, at least, a wide variety of new institutional forms are likely to emerge from old ones, and as in the period of managerial capitalism, alternative approaches to productive activity will also emerge.

Our role as social scientists is not to be the co-architects of a financial model of the firm that heightens inequality, but to be the co-architects of social models that equalise the distribution of returns to working people. This is a period of intellectual discovery and excitement. Our job as social scientists is to go to the field: observe, monitor, and evaluate social experiments; and collaborate across disciplines to uncover the underlying principles of successful new models even as they operate with different functional forms or distinct institutional configurations in different parts of the world.

\section{REFERENCES}

Abell, Hilary (2014), 'Worker Cooperatives: Pathways to Scale' (Washington, DC, The Democracy Collaborative).

http://community-wealth.org/sites/clone.community-wealth.org/files/downloads/WorkerCoopsPathwaysToScale.pdf

Alexander, Brian (2017), Glass House: The 1\% and the Shattering of the All-American Town (New York, St. Martin's Press).

Allegretto, Sylvia \& Reich, Michael (2018), 'Are Local Minimum Wages Absorbed by Price Increases? Estimates from Internet-based Restaurant Menus', Industrial and Labor Relations Review, 71: 35-63. 
Allegretto, Syliva, Dube, Arin, Reich, Michael \& Zipperer, Ben (2017), 'Credible Research Designs for Minimum Wage Studies: A Response to Neumark, Salas, and Wascher', Industrial and Labor Relations Review, 70: 559-92. https://doi.org/10.1177/0019793917692788

Amin, Ash (ed.) (2009), The Social Economy: International Perspectives on Economic Solidarity (London and New York, Zed Books).

Appelbaum, Eileen (2017), 'Domestic Outsourcing, Rent Seeking, and Increasing Inequality', David Gordon Memorial Lecture, Allied Social Science Association Meetings, 6 January, Review of Radical Political Economics 49: 513-28. https://doi.org/10.1177/0486613417697121

Appelbaum, E., Bailey, T., Berg, P. \& Kalleberg, A. (2000), Manufacturing Advantag. (Ithaca, NY, ILR Press).

Appelbaum, Eileen \& Batt, Rosemary (2014), Private Equity at Work: When Wall Street Manages Main Street (New York, Russell Sage Foundation).

Appelbaum, Eileen \& Batt, Rosemary (2016), 'Fees, Fees, and More Fees: How Private Equity Abuses its Limited Partners and U.S. Taxpayers', Center for Economic and Policy Research, Washington, DC. http://cepr.net/images/stories/reports/private-equity-fees-2016-05.pdf

Appelbaum, Eileen \& Batt, Rosemary (2018), 'Are Lower Private Equity Returns the New Normal?', in Kevin Amess, Nick Bacon \&Mike Wright (eds) The Routledge Companion to Management Buyouts (London, Routledge).

Azzellini, Dario (2017), Communes and Workers' Control in Venezuela: Building 21st Century Socialism from Below (Amsterdam, Brill).

Bain \& Company (2016), 'Bain Global Private Equity Report 2016', Bain \& Company, Boston, MA. http://www.bain.com/publications/business-insights/global-private-equity-report.aspx

Bair, Jennifer (2009), 'Global Commodity Chains: Genealogy and Review', in Frontiers of Commodity Chain Research, Jennifer Bair (ed.) (Stanford, CA, Stanford University Press), 1-34.

Barney, Jay (1991), 'Firm Resources and Sustained Competitive Advantage', Journal of Management, 17(1): 99-120. https://doi.org/10.1177/014920639101700108

Barth, E., Bryson, A., Davis, J. C. \& Freeman, R. (2014), 'It's Where You Work: Increases in Earnings Dispersion Across Establishments and Individuals in the US', Working Paper 20447, National Bureau of Economic Research, Cambridge, MA.

Batt, Rosemary (2002), 'Managing Customer Services: Human Resource Practices, Quit Rates, and Sales Growth', Academy of Management Journal, 45: 587-97. https://doi.org/10.2307/3069383

Batt, Rosemary (2018), 'The Financial Model of the Firm, the "Future of Work", and Employment Relations', in A. Wilkinson, T. Dundon, J. Donaghey \& A. Colvin (eds) The Routledge Companion to Employment Relations (London, Routledge).

Batt, Rosemary \& Nohara, Hiro (2009), 'How Institutions and Business Strategies Affect Wages: A Cross National Study of Call Centers', Industrial and Labor Relations Review, 62: 533-52. https://doi.org/10.1177/001979390906200404

Becker, Gary (1964), Human Capital: A Theoretical and Empirical Analysis, With Special Reference to Education (Chicago, IL, University of Chicago Press).

Bentham, Justin, Bowman, Andrew, de la Cuesta, Marta, Engelen, Ewald, Ertürk, Ismail, Folkman, Peter, Froud, Julie, Johal, Sukhdev, Law, John, Leaver, Adam, Moran, Mick \& Williams, Karel (2013), 'Manifesto for the Foundational Economy', Working Paper 131, Centre for Research on Socio-Cultural Change (CRESC), University of Manchester, Manchester. https://foundationaleconomycom.files.wordpress.com/2017/01/wp131.pdf

Bernhardt, Annette, Batt, Rosemary, Houseman, Susan \& Appelbaum, Eileen (2016), 'Domestic Outsourcing in the U.S.: A Research Agenda to Assess Trends and Effects on Job Quality', Department of Labor Conference Paper on the Future of Work, 10 December.

Birchall, Johnston (2013), 'The Governance of Large Co-operative Businesses', Co-operatives UK. https://www.uk.coop/newsroom/governance-large-co-operative-businesses 
Birchall, Johnston \& Ketilson, Lou Hammond (2009), 'Resilience of the Cooperative Model in Times of Crisis', Sustainable Enterprise Programme, International Labour Organization, Geneva.

http://www.ilo.org/wcmsp5/groups/public/---ed_emp/---emp_ent/documents/publication/ wcms_108416.pdf

Blonigen, Bruce \& Pierce, Justin (2015), 'The Effect of Mergers and Acquisitions on Market Power and Efficiency'. http://pages.uoregon.edu/bruceb/blonigen_pierce_aug2015.pdf

Cable, Dan \& Vermeulen, Freek (2016), 'Stop Paying Executives for Performance', Harvard Business Review, February. https://hbr.org/2016/02/stop-paying-executives-for-performance

Carayon, P. (1993), 'Effect of Electronic Performance Monitoring on Job Design and Worker StressReview of the Literature and Conceptual-Model', Human Factors, 35:385-95. https://doi.org/10.1177/001872089303500301

CDFI Fund (2016), 'SNAP STAT: Sizing Up Certified CDFIs', Community Development Financial Institutions, 1 June. https://www.cdfifund.gov/Documents/Snap\%20Stat\%20June \%201,\%202016.pdf

Chandler, Adam (2016), 'Minimum-wage Increases: Another Big Winner on Election Night: At least 2 Million Americans Will Get Raises after Ballot Measures Passed in a Handful of States', 9 November. https://www.theatlantic.com/business/archive/2016/11/minimum-wage-2016/507158/

Chittoor, Raveendra, Narain, Arohini, Vyas, Richa, \& Tolia, Chetan (2013), 'Creating a Corporate Advantage: The Case of the Tata Group', Indian School of Business.

Christensen, Clayton \& Clark, Kim (2014), 'The Capitalist's Dilemma: Are Investors Bad for Business?', Harvard Business Review, June: 60-8

Christensen, Clayton, Alton, Richard, Rising, Curtis \& Waldeck, Andrew (2011), 'The Big Idea: The New M\&A Playbook” Harvard Business Review, March: 48-57.

Clement, Michel (2009), 'Co-operative Development in Québec', Développement économique, innovation et exportation, Québec.

Combs, J., Liu, Y., Hall, A. \& Ketchen, D. (2006), 'How Much Do High-performance Work Practices Matter? A Meta-analysis of their Effects on Organizational Performance', Personnel Psychology, 59: 501-28. https://doi.org/10.1111/j.1744-6570.2006.00045.x

Cordero-Guzmán, Héctor (2015), 'Worker Centers, Worker Center Networks, and the Promise of Protections for Low-wage Workers', WorkingUSA: The Journal of Labor and Society, 18: 31-57. https://doi.org/10.1111/wusa.12152

Daggers, Jess \& Nicholls, Alex (2016), 'The Landscape of Social Impact Investment Research: Trends and Opportunities', Said Business School, Oxford.

http://www.sbs.ox.ac.uk/sites/default/files/research-projects/CRESSI/docs/the-landscape-ofsocial-impact-investment-research.pdf

Davis, Gerald (2016), The Vanishing American Corporation: Navigating the Hazards of a New Economy (Oakland, CA, Berrett-Koehler).

Deery, S., Iverson, R. D. \& Walsh, J. (2002), 'Work Relationships in Telephone Call Centers: Understanding Emotional Exhaustion and Employee Withdrawal', Journal of Management Studies, 39: 471-97. https://doi.org/10.1111/1467-6486.0030

Deloitte (2016), 'M\&A Trends Report 2016, Year-end Edition', Deloitte Development LLC. https://www2.deloitte.com/us/en/pages/mergers-and-acquisitions/articles/ma-trends-report.html

Denning, S. (2013), 'What Went Wrong at Boeing?', Forbes, 21 January. https://doi.org/10.1108/10878571311323208

Diamantopoulos, Mitch \& Bourgeois, April (2014), 'Worker Co-operative Development in Saskatchewan: The Promise, the Problems, and the Prospects', Research Report 14-5, Community-University Institute for Social Research, University of Saskatchewan, Saskatoon. 
Doellgast, Virginia, Sarmiento-Mirwaldt, Katja \& Benassi, Chiara (2016), 'Institutions, Cost Structures, and the Politics of Externalization: Explaining Variation in Boundary Strategies for Call Center Jobs', Industrial and Labor Relations Review, 69 551-78. https://doi.org/10.1177/0019793915624088

Doellgast, V., Lillie, N. \& Pulignano, V. (eds) (2017), Reconstructing Solidarity: Labour Unions, Precarious Work, and the Politics of Institutional Change in Europe (Oxford, Oxford University Press).

Drahokoupil, J. (ed.) (2015), 'The Outsourcing Challenge: Organizing Workers across Fragmented Production Chains', European Trade Union Institute.

www.etui.org/Publications2/Books/The-outsourcing-challenge-organizing-workers-acrossfragmented-production-networks

Dube, Arindrajit \& Kaplan, Ethan (2010), 'Does Outsourcing Reduce Wages in the Low-wage Service Occupations? Evidence from Janitors and Guards', Industrial and Labor Relations Review, 63: 287-306. https://doi.org/10.1177/001979391006300206

Erickson, Chris, Milkman, Ruth, Mitchell, Daniel \& Wong, Kent (2002), 'Justice for Janitors in Los Angeles: Lessons from Three Rounds of Negotiations', British Journal of Industrial Relations, 40: 543-67. https://doi.org/10.1111/1467-8543.00246

FDIC (2016), ‘CDFI Organizational Structures', Federal Deposit Insurance Corporation. https://www.fdic.gov/consumers/community/cdfi/cdfis_sectionii.pdf

Fight for Fifteen (2015), 'Chicago Fast-food Workers Strike As Campaign For Higher Pay, Better Rights Spreads to $150+$ US Cities, Three-dozen Countries'.

http://fightfor15chicago.org/en/chicago-fast-food-workers-strike-as-campaign-for-higher-paybetter-rights-spreads-to-150-us-cities-three-dozen-countries/

Fine, Janice (2005), Worker Centers: Organizing Communities at the Edge of the Dream (Washington, DC, Economic Policy Institute).

Foley, M., Ruser, J., Shor, G., Shuford, H. \& Sygnatur, E., (2014), 'Contingent Workers: Workers' Compensation Data Analysis Strategies and Limitations', American Journal of Industrial Medicine, 57: 764-75. https://doi.org/10.1002/ajim.22302

Forbes (2009), 'Special Report: The World's Biggest Companies'. http://www.forbes.com/2009/04/08/worlds-largest-companies-business-global-09-global_land. html

Froud, J., Johal, S., Leaver, A., \& Williams, K. (2006), Financialization and Strategy: Narrative and Numbers: Narrative and Numbers (London, Routledge).

Gereffi, G. \& Koreniewicz, M. (eds) (1994), Commodity Chains and Global Capitalism (Westport, CT, Greenwood Press).

Gleeson, Shannon (2012), Conflicting Commitments: The Politics of Enforcing Immigrant Worker Rights in San Jose and Houston (Ithaca, NY, Cornell University Press). https://doi.org/10.7591/cornell/9780801451218.001.0001

Goldschmidt, Deborah \& Schmieder, Johannes F. (2015), 'The Rise of Domestic Outsourcing and the Evolution of the German Wage Structure', IZA Discussion Paper No. 9194, Institute for the Study of Labor, Bonn.

Gospel, Howard, Pendleton, Andrew \& Vitols, Sigurt (eds) (2014), Financialisation, New Investment Funds, and Labour: An International Comparison (Oxford, Oxford University Press). https://doi.org/10.1093/acprof:oso/9780199653584.001.0001

Greenhouse, Steven (2016), 'Thousands of Fight for 15 Protesters Rise up in 340 Cities across the US', The Guardian, 29 November.

https://www.theguardian.com/us-news/2016/nov/29/fight-for-15-protest-minimum-wage-fastfood-airport-workers

Grullon, Gustavo, Larkin, Yelena \& Michaely, Roni (2015), 'The Disappearance of Public Firms and the Changing Nature of U.S. Industries', SSRN, May. http://papers.ssrn.com/sol3/papers.cfm?abstract_id=2612047 
Guillén, Mauro \& García-Canal, Esteban (2009), 'The American Model of the Multinational Firm and the "New" Multinationals from Emerging Economies', Academy of Management Perspectives, 23(2): 23-35. https://doi.org/10.5465/AMP.2009.39985538

Hall, Peter \& Soskice, David (2001), 'An Introduction to Varieties of Capitalism', in David Soskice (ed.) Varieties of Capitalism: The Institutional Foundations of Comparative Advantage (New York, Oxford University Press), 1-70. https://doi.org/10.1093/0199247757.003.0001

Handwerker, Elizabeth Weber (2015), 'Increased Concentration of Occupations, Outsourcing, and Growing Wage Inequality in the United States', working paper, U.S. Bureau of Labor Statistics, 5 June. http://www.iza.org/conference_files/inequality_2015/handwerker_e20486.pdf

Handwerker, E. \& Spletzer, J., (2015), 'The Concentration of Occupations and the Role of Establishments in Wage Inequality', IZA Discussion Paper No. 9294, Institute for the Study of Labor, Bonn.

Harding, David \& Rouse, Ted (2007), 'Human Due Diligence', Harvard Business Review, April: 124-31.

Hart, Oliver \& Zingales, Luigi (2017), 'Companies Should Maximize Shareholder Welfare Not Market Value', Journal of Law, Finance, and Accounting, 2: 247-74. https://doi.org/10.1561/108.00000022

Hartung, Adam (2016), 'JPMorgan Chase and Starbucks Minimum Wage Increases-Just Following Trends', Forbes, 13 July. https://www.forbes.com/sites/adamhartung/2016/07/13/starbucks-and-jpmorganchase-minimumwage-increases-just-following-trends/\#385811a96088

Holman, D., Chissick, C., \& Totterdell, P (2002), 'The Effects of Performance Monitoring on Emotional Labour and Well-being in Call Centres', Motivation and Emotion, 26(1): 57-81. https://doi.org/10.1023/A:1015194108376

Howard, Ted \& Norris, Tyler (2015) 'Can Hospitals Heal America's Communities?', The Democracy Collaborative, Washington, DC.

http://democracycollaborative.org/content/can-hospitals-heal-americas-communities

ICA (2014), 'Blueprint for the Co-operative Decade', International Cooperative Alliance. http://ica.coop/en/blueprint-co-op-decade

IFA (2013), 'Economic outlook for franchising', International Franchise Assocation. http://www.franchise.org/uploadedFiles/Prospective_Franchisee/News/EconomicImpact11.pdf

Jacobs, Michael \& Mazzucato, Mariana (eds) (2016), Rethinking Capitalism: Economics and Policy for Sustainable and Inclusive Growth (Chichester, John Wiley).

Jensen, Michael \& Meckling, William (1976), 'Theory of the Firm: Managerial Behavior, Agency Cost, and Ownership Structure', Journal of Financial Economics, 3: 305-60

Jensen, Michael C. \& Murphy, Kevin J. (1990), 'CEO Incentives-It's Not How Much You Pay But How', Harvard Business Review, May-June: 138-53. https://doi.org/10.1016/0304-405X(76)90026-X

Ji, MinWoong \& Weil, David (2015), 'The Impact of Franchising on Labor Standards Compliance', Industrial and Labor Relations Review 68: 977-1006. https://doi.org/10.1177/0019793915586384

Jiang, K., Lepak, D. P., Hu, J. \& Baer, J. C. (2012), 'How Does Human Resource Management Influence Organizational Outcomes: A Meta-analytic Investigation of Mediating Mechanisms', Academy of Management Journal, 55: 1264-94. https://doi.org/10.5465/amj.2011.0088

Khanna, Tarun \& Palepu, Krishna (2006), 'Emerging Giants: Building World-class Companies in Developing Countries', Harvard Business Review, October.

Krippner, Greta (2011), Capitalizing on Crisis: The Political Origins of the Rise of Finance (Cambridge, Harvard University Press).

Lakhani, Tashlin (2016), 'The Effect of Ownership on Human Resource Practices in Networked Firms: Evidence from a Franchise System', manuscript, December.

Lambert, Craig (2015), Shadow Work: The Unpaid, Unseen Jobs That Fill Your Day (New York, Counterpoint).

Latinne, Amanda (2014), The Mondragon Cooperatives: Workplace Democracy and Globalization (Cambridge, Intersentia). 
Lazonick, William (1992), 'Controlling the Market for Corporate Control: The Historical Significance of Managerial Capitalism', Industrial and Corporate Change, 1: 445-88.

https://doi.org/10.1093/icc/1.3.445

Lazonick, William (2009), Sustainable Prosperity in the New Economy (Kalamazoo, MI, Upjohn Institute). Lazonick, William (2014), 'Profits without Prosperity', Harvard Business Review, September: 3-11.

Lepak, David \& Snell, Scott (1999), 'The Human Resource Architecture: Toward a Theory of Human Capital Allocation and Development', Academy of Management Review, 24(1): 31-48.

Lucier, Chuck, Schuyt, Rob \& Tse, Edward (2004), 'CEO SUCCESSION 2004: The World's Most Prominent Temp Workers', Booz Allen.

http://www.boozallen.com/content/dam/boozallen/media/file/145709.pdf

MacDonald, Ian \& Dupuis, Mathieu (2017), 'A Decent Return? Quebec's Solidarity Fund at Work', paper presented to the 69 th annual meeting of the Labor and Employment Relations Association (LERA), Anaheim, CA, 3 June.

MacDuffie, John Paul (1995), 'Human Resource Bundles and Manufacturing Performance: Organizational Logic and Flexible Production Systems in the World Auto Industry', Industrial and Labor Relations Review, 48: 197-201. https://doi.org/10.1177/001979399504800201

Marchington, Mick, Grimshaw, Damian, Rubery, Jill \& Willmott, Hugh (eds) (2005), Fragmenting Work: Blurring Organizational Boundaries and Disordering Hierarchies (Oxford, Oxford University Press).

Marginson, Paul (2016), 'Governing Work and Employment Relations in an Internationalized Economy: The Institutional Challenge', Industrial and Labor Relations Review, 69: 1033-55. https://doi.org/10.1177/0019793916654891

Martin, Roger (2016), 'The One Thing You Need to Get Right', Harvard Business Review, June.

Massoudi, Arash, Fontanella-Khan, James \& Weinland, Don (2016), 'Final Quarter of Blockbuster Deals Boosts M\&A Activity', Financial Times, 29 December.

https://www.ft.com/content/a77f7100-cda7-11e6-864f-20dcb35cede2

Mayer, Colin (2013), Firm Commitment (Oxford, Oxford University Press).

Mayer, Colin (2016), 'Reinventing the Corporation', Journal of the British Academy, 4: 53-72. https://doi.org/10.5871/jba/004.053

Mendell, Margarite (2009), 'The Three Pillars of the Social Economy', in Ash Amin (ed.) The Social Economy: International Perspectives on Economic Solidarity (London and New York, Zed Books).

Morris, J. A., (1999), 'Injury Experience of Temporary Workers in a Manufacturing Setting: Factors that Increase Vulnerability', Workplace Health and Safety, 47(10): 470-8.

Muzaffar, S., Cummings, Gerald Hobbs, K., Allison, P. \& Kreiss, K., (2013), 'Factors Associated with Fatal Mining Injuries among Contractors and Operators', Journal of Occupational and Environmental Medicine, 55: 1337-44. https://doi.org/10.1097/JOM.0b013e3182a2a5a2

NELP (2016), 'Fight for \$15 Impact Report: Raises for 17 Million Workers, 10 Million Going to \$15', National Employment Law Project.

http://www.nelp.org/publication/fight-for-15-impact-report-raises-for-17-million-workers-10-milliongoing-to-15/

Nicholls, Alex, Emerson, Jed \& Paton, Rob (eds) (2015), Social Finance (Oxford, Oxford University Press). https://doi.org/10.1093/acprof:oso/9780198703761.001.0001

OFN (2010), 'Opportunity Finance Network, Goldman Sachs' 10,000 Small Business Initiative Partner to Increase Small Business Lending', Opportunity Finance Network. http://ofn.org/sites/default/files/resources/PDFs/Press\%20Docs/2010/10kSB_CDFI.pdf

Oi, Walter (1962), 'Labor as a Quasi-fixed Factor,' Journal of Political Economy, 70: 538-55. https://doi.org/10.1086/258715

Olsen, Erik K. (2013), 'The Relative Survival of Worker Cooperatives and Barriers to Their Creation', in Advances in the Economic Analysis of Participatory \& Labor-managed Firms Volume 14 (Bingley, Emerald Insight), 295-325. https://doi.org/10.1108/S0885-3339(2013)0000014005 
Piore, Michael \& Sabel, Charles (1984), The Second Industrial Divide: Possibilities for Prosperity (New York, Basic Books).

PitchBook (2016), 'PitchBook 2016 Annual M\&A Report' (Seattle, WA, PitchBook).

Prahalad, C. K., \& Hamel, Gary (1990), 'The Core Competencies of the Corporation', Harvard Business Review, 68(3): 79-91.

Preqin (2016), '2016 Preqin Global Hedge Fund Report'.

https://www.preqin.com/docs/samples/2016-Preqin-Global-Hedge-Fund-Report-Sample-Pages. pdf

PWC (2015), '2015 CEO Success Study', PricewaterhouseCoopers. http://www.strategyand.pwc.com/ceosuccess

Ramachandran, J., Manikandan, K. S. \& Pant, Anirvan (2013), 'Why Conglomerates Thrive (Outside of the U.S.)', Harvard Business Review, December.

Ranis, Peter (2011) Cooperatives Confront Capitalism (London, Zed Books).

Rebitzer, J. B., (1995), 'Job Safety and Contract Workers in the Petrochemical Industry', Industrial Relations, 34(1): 40-57. https://doi.org/10.1111/j.1468-232X.1995.tb00359.x

Sakinç, Mustafa Erdem (2017) 'Share Repurchases in Europe', unpublished research note.

Schneiberg, Marc (2011),'Toward an Organizationally Diverse American Capitalism? Cooperative, Mutual, and Local, State-owned Enterprise', Seattle University Law Review, 34: 1409-34.

Smith, Wendy K., Gonin, Michael \& Besharov, Marya (2013), 'Managing Social-Business Tensions: A Review and Research Agenda for Social Enterprise', Business Ethics Quarterly, 23: 407-42. https://doi.org/10.5840/beq201323327

Sorkin, Andrew Ross (2017), 'Buffett Asks Big Money: Why Pay High Fees?', NYT Deal Book, 27 February.

https://www.nytimes.com/2017/02/27/business/dealbook/buffett-asks-big-money-why-pay-highfees.html?ref $=$ dealbook\&_r $=0$

Stout, Lynn (2012), The Shareholder Value Myth (San Francisco, CA, Berrett-Koehler).

Szekely, Francisco \& Dossa, Zahir (2014), 'Can Social Enterprises Scale While Remaining Sustainable? The Mondragon Cooperatives', Harvard Business School, Cambridge, MA.

Tang, C. S., \& Zimmerman, J. (2009), 'Managing New Product Development and Supply Chain Risks: The Boeing 787 Case', Supply Chain Forum: An International Journal, 10: 74-86. https://doi.org/10.1080/16258312.2009.11517219

Tang, Christopher, Yeh, Brian \& Zimmerman, Joshua (2013), 'Boeing's 787 Dreamliner: A Dream or a Nightmare?'.

http://blogs.anderson.ucla.edu/global-supply-chain/2013/05/boeings-787-dreamliner-a-dream-ora-nightmare-by-christopher-tang-based-on-work-with-brian-yeh-pwc-advisory-and-joshua.html

Tonello, Matteo \& Reda, James (2015), Key Findings from CEO and Executive Compensation Practices: 2015 Edition (New York, The Conference Board and Arthur J. Gallagher \& Co), 27 August.

Towers Watson (2015), 'CEO Pay in the Eurotop 100: Insights on Similiarities and Differences in CEO Pay across Europe', Towers Watson, London.

Tremlett, Giles (2013), 'Mondragon: Spain's Giant Co-operative Where Times are Hard but Few Go Bust', The Guardian, 7 March.

University of Wisconsin, Center for Cooperatives (2010), 'Cooperatives in the US Economy', Center for Cooperatives, University of Wisconsin, Madison, WI, 6 May. http://reic.uwcc.wisc.edu/summary

US Census Bureau (2010), 'Census Bureau's First Release of Comprehensive Franchise Data Shows Franchises Make up More than 10 Percent of Employer Businesses'.

http://www.census.gov/newsroom/releases/archives/economic_census/cb10-141.html 
Virgeo Eiris (2017), 'The Human Rights Responsibilities of Business in a Changing World: How Companies Across the Globe are Addressing Key Areas of Human Rights'.

http://www.vigeo-eiris.com/en/2017/02/23/the-human-rights-responsibilities-of-business-in-a-changingworld/

Weil, David (2014), The Fissured Workplace (Cambridge, MA, Harvard University Press). https://doi.org/10.4159/9780674726123

Zahn, Max (2016), 'How Can the Fight for 15 Move From Winning Wage Increases to Winning a Union?', In These Times, 2 May.

http://inthesetimes.com/working/entry/19094/fight-for-15-union-minimum-wage-seiu

Note on the author: Rosemary Batt is the Alice Hanson Cook Professor of Women and Work at the ILR School, Cornell University. She is a Professor in Human Resource Studies and International and Comparative Labor and editor of the ILR Review. She received her BA from Cornell University and her $\mathrm{PhD}$ from the Sloan School of Management, MIT. Her research focuses on the field of management and employment relations, with particular emphasis on explaining how and why firm-level strategies affect organisational effectiveness and the quality of jobs for workersincluding wages, working conditions, and inequality.

Recent publications include:

Appelbaum, Eileen \& Batt, Rosemary (2014), Private Equity at Work: When Wall Street Manages Main Street (New York, Russell Sage Foundation).

Appelbaum, Eileen \& Batt, Rosemary (2018), 'Are Lower Private Equity Returns the New Normal?', in Kevin Amess, Nick Bacon \&Mike Wright (eds) The Routledge Companion to Management Buyouts (London, Routledge).

Batt, Rosemary (2018), 'The Financial Model of the Firm, the "Future of Work", and Employment Relations', in A. Wilkinson, T. Dundon, J. Donaghey \& A. Colvin (eds) The Routledge Companion to Employment Relations (London, Routledge).

Liu, Xiangmin, van Jaarsveld, Danielle, Batt, Rosemary \& Frost, Ann C, (2014), 'The Influence of Capital Structure on Strategic Human Capital: Evidence from US and Canadian Firms', Journal of Management, 40: 422-48.

rb41@cornell.edu.

To cite the article: Rosemary Batt (2018), 'When Wall Street manages Main Street: Managerial dilemmas, sustainability, and inequality', Journal of the British Academy, 6: 65-96.

DOI https://doi.org/10.85871/jba/006.065

This article is licensed under a

Creative Commons Attribution-NonCommercial-NoDerivs 3.0 Unported License.

Journal of the British Academy (ISSN 2052-7217) is published by

The British Academy - the national academy for the humanities and social sciences. 10-11 Carlton House Terrace, London, SW1Y 5AH www.britishacademy.ac.uk 
